\title{
A Bibliometric Analysis of Organizational Climate of Schools
}

\author{
Hui-Wen Vivian Tang and Mu-Shang Yin
}

\begin{abstract}
To examine bibliometric characteristics of research studies on school climate, the present study is a systematic quantitative estimate of school climate research available through Thomson Reuters ISI Web of Science database, aiming at updating our understanding regarding the ongoing research trends and publication patterns of literature for the years 2010 through 2016. Analyzed parameters included: (1) Total numbers and characteristics of publications, (2) Publication patterns by languages and countries/territories, (3) Publication patterns by source titles and subject areas. Results of the current analysis may open up new avenues for continuous bibliometric investigations of school climate literature for generating unique insights into the direction of not only a particular data source during a given time frame, but also the research dynamics and evolution within which the literature on school climate exists.
\end{abstract}

Index Terms - Bibliometric analysis, citation analysis, global citation score, ISI Web of Science, school climate.

\section{INTRODUCTION}

A historical look at the field of school climate research over the past half century shows profound linkages between positive school climate and a myriad of school outcomes. Although positive climate is potentially an important vehicle in quest of different aspects of organizational health, components of school climate are seldom reviewed and synthesized in studies from a bibliometric perspective. the present study intends to document a full account of the path that research on school climate have taken in the past. To gauge a coherent situated understanding of school climate throughout the past 7 years, a bibliometric analysis was adopted to systematically evaluate publication performance and trend of literature on school climate during the time span of 2010 to 2016 with the primary aim of quantifying bibliometric characteristics of published papers available through Thomson Reuters ISI Web of Science database (ISI WoS).

\section{LITERATURE REVIEW}

\section{A. Organizational Climate of Schools}

In identifying the concept of school climate, Halpin and Croft in 1963, ushered in their pioneering study of two metaphors that are highly interesting to researchers:

Manuscript received December 21, 2017; revised March 12, 2018.

Hui-Wen Tang is with the Ming Chuan University, Taiwan (e-mail: kshvt00@hotmail.com).

Mu-Shang Yin is with the Hsing Wu University, Taiwan (email: yin_max@hotmail.com) personality and health [1]. The personality metaphor of school climate is often thought as the 'personality' of the school and categorized along a continuum from open to closed. An open school climate is characterized by maintaining school safety and order, where the principal is supportive of teachers and teamwork, and where teachers are respectful of each other and are committed to helping students succeed [1], [2]. In a closed school climate, the principal is considered as being rigid, controlling, and unsympathetic [3]. The principal and teachers do not work together, and the faculty is uncaring toward students. Another early perspective postulated by Miles (1965) for investigating the nature of school climate is organizational health. Miles' conceptual framework for examining a total of ten properties of schools were configured into three general dimensions reflecting the task needs of schools as a social system, the maintenance needs of the internal state of schools, and the needs for organizational growth and development [3].

A promising new perspective on essential areas of focus for informing previous school climate research comes from a synthesized review in 2013 [4], which detailed from an astounding diversity of more than 200 studies into five common dimensions of school climate: (a) Safety, (b) Relationships, (c) Teaching and Learning, (d) Institutional Environment, and (e) the School Improvement Process. More recently, a review on school climate research identified 13 dimensions clustered under four domains of school climate: (a) academic (i.e., teaching and learning, leadership, professional development); (b) community (i.e., quality of relationships, connectedness, respect for diversity, partnerships); (c) safety (i.e., social and emotional safety, physical safety, discipline and order); and (d) institutional environment (i.e., environmental adequacy, structural organization, availability of resources). What the ever-growing research studies on school climate have in common is the aim of casting positive light on school effectiveness and improvement [4].

\section{B. Instruments for Assessing School Climate}

Building on Hoy and Hannum's root metaphor of "personality" in which the climates of schools have been portrayed along a continuum from an open to closed, the initial Organizational Climate Description Questionnaire (OCDQ) was constructed specifically to measure eight dimensions of organizational life in elementary school climates [3]. Four of the dimensions were comprised of measures of characteristics of the group (Disengagement, Hindrance, Esprit and Intimacy), while the other four contained measures of the characteristics of the principal as leader (Aloofness, Production Emphasis, Thrust and Consideration). 
The widespread usefulness of the original OCDQ led to subsequent generations of four separate versions of OCDQ, namely the OCDQ-RE developed for use in elementary schools, the OCDQ-RM revised for middle schools, the OCDQ-RS for secondary schools, and the OCDQ-HE for use in higher education settings [3], [5]-[7]. the Organizational Health Index (OHI) was developed based specifically on Halpin and Croft's delineation of the health metaphor [1].

Similar to the OCDQ, three separate versions of OHI exist to measure teachers' and administrators' perceptions of organizational health to overall school functioning at the elementary, middle, and secondary school levels [7]. After a series of exploratory factor analyses, seven uni-dimensional scales of school health were labeled into the technical, managerial, and institutional levels. Institutional integrity serves as an indicator of health at the institutional level. Principal influence, consideration, initiating structure, and resource support provide measures of the health of the managerial system. Morale and academic emphasis are indices of health at the technical level [7].

To access preliminary bibliometric characteristics employed by researchers investigating school climate, the present study is a systematic quantitative estimate of school climate research, aiming at updating our understanding regarding the ongoing research trends and publication patterns of literature for the years 2010 through 2016.

\section{DATA SOURCES AND METHOD}

Bibliometrics, a research technique with its tradition root in library and information sciences, has now been widely applied to approximating the growth of literature, scientific progress, current state and paradigm shifts through quantitative evaluations of empirical data in the form of publication productivity and citation analysis within a given topic, field, institute, or country [8], [9]. HistCite, a visualization-based tool, is used to structuralize citation properties by producing a complementary graphic representation of all LSA studies extracted by the present study.

The dataset deployed by this study consists of bibliographic metadata associated with a continuous cumulative coverage of more than 40 million source items tracked by Thomson Reuters ISI Web of Science ${ }^{\circledR}$ (ISI WoS) database (formerly known as ISI Web of Knowledge). The Thomas Reuters Web of Science ${ }^{\circledR}$ core collection has been recognized as one of the most widely used tools to extrapolate bibliometric data. Science Citation Index - Expanded (SCI), Social Science Citation Index (SSCI) and Arts and Humanity Citation Index (A\&HCI) are the three notable citation index databases comprised in ISI WoS core collection. SCI covers approximately 8,000 major science and engineering journals since 1955, SSCI contains more than 3,000 world leading scientific and technical journals starting from 1956, and more than 1,700 arts and humanities journals since 1975 .

Research results were retrieved from the ISI WoS database using the key term of "school climate" under the search "Topic" and "Title" sections beginning with January 1, 2010 to a cutoff date of December 31, 2016. Document type was limited to journal articles; therefore, conference proceedings, book reviews, notes were excluded from the final analysis. Data were extracted and analyzed via the ISI WoS in plain text file and registered into the ISI.exe file format for detailed analysis by HistCite software. Analyzed parameters included: (1) Total numbers and characteristics of publications, (2) Publication patterns by languages and countries/territories, (3) Publication patterns by source titles and subject areas.

\section{DATA ANALYSIS RESULTS}

\section{A. Total Numbers and Citation Counts of Publications}

As shown in Table I, the total retrieved documents after removing duplicate records were 475 (data retrieved in August 31, 2017). From 2010 to 2016, the annual number of publications on school climate extracted from ISI WoS databases fluctuated slightly from 41 in 2010, 43 in 2011, 63, 59 and 64 in 2012, 2013 and 2014, respectively. Then, it increased gradually and reached 104 in 2015 and 101 in 2016. TABLE I: DISTRIBUTION OF SCHOOL CLIMATE RESEARCH BY PUBLICATION YEARS AND GCS

\begin{tabular}{lll}
\hline \hline Publication Year & Recs & GCS \\
\hline 2010 & 41 & 1045 \\
2011 & 43 & 690 \\
2012 & 63 & 731 \\
2013 & 59 & 530 \\
2014 & 64 & 396 \\
2015 & 104 & 299 \\
2016 & 101 & 138 \\
Total & 475 & 3829 \\
\hline \hline
\end{tabular}

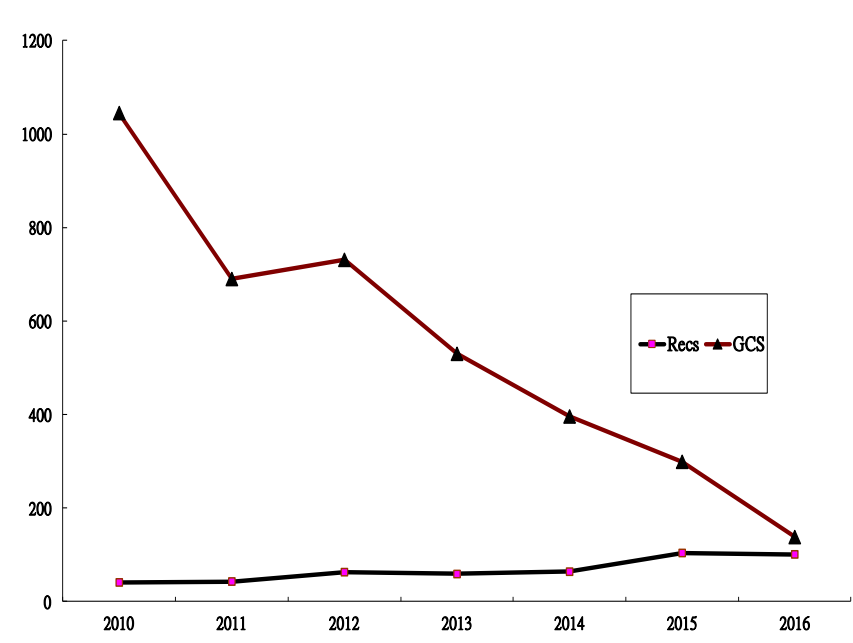

Fig.1. The linear annual growth rate of school climate research

Annual distribution of Global Citation Score (GCS) as shown in Table I and Fig. 1 exhibits detailed chronological patterns of impacts on the school climate literature on the research community. With regard to citation performances, Total GCSs of 1045 in 2010, 690 in 2011 and 138 in 2016 showed that citation frequencies dropped in an annual pattern. As can be observed, the aggregate data indicated that the astounding proportion of the citations to school climate research works reached their peaks in early years, evidencing their accumulating and far-reaching impacts on later works.

The top ten most cited publications were tabulated above (see Table II), showing that authors whose articles were 
written in English and affiliated with English spoken countries were favored by the research community. Seven of the 10 articles were published in the year of 2010. Topics in relation to impacts of school climate as support systems on students' psychological health and well-being stand first with both high quantity and quality status of scientific productions and citations.

TABLE II: THE TOP TEN MOST CITED WORKS BY GCS

\begin{tabular}{|c|c|c|c|}
\hline Year & Authors & Title & GCS \\
\hline 2010 & $\begin{array}{l}\text { McGuire et } \\
\text { al. (USA) }\end{array}$ & $\begin{array}{l}\text { School Climate for Transgender Youth: } \\
\text { A Mixed Method Investigation of } \\
\text { Student Experiences and School } \\
\text { Responses }\end{array}$ & 104 \\
\hline 2010 & $\begin{array}{l}\text { Gregory et } \\
\text { al. (USA) }\end{array}$ & $\begin{array}{l}\text { Authoritative School Discipline: High } \\
\text { School Practices Associated With Lower } \\
\text { Bullying and Victimization }\end{array}$ & 88 \\
\hline 2010 & $\begin{array}{l}\text { Eliot et al. } \\
\text { (USA) }\end{array}$ & $\begin{array}{l}\text { Supportive school climate and student } \\
\text { willingness to seek help for bullying and } \\
\text { threats of violence }\end{array}$ & 77 \\
\hline 2012 & $\begin{array}{l}\text { Collie et } \\
\text { al.(Canada) }\end{array}$ & $\begin{array}{l}\text { School Climate and Social-Emotional } \\
\text { Learning: Predicting Teacher Stress, Job } \\
\text { Satisfaction, and Teaching Efficacy }\end{array}$ & 66 \\
\hline 2010 & $\begin{array}{l}\text { Zullig et al. } \\
\text { (USA) }\end{array}$ & $\begin{array}{l}\text { School Climate: Historical Review, } \\
\text { Instrument Development, and School } \\
\text { Assessment }\end{array}$ & 58 \\
\hline 2010 & $\begin{array}{l}\text { Sawyer et } \\
\text { al. } \\
\text { (Australia) }\end{array}$ & $\begin{array}{l}\text { School-based prevention of depression: } \\
\text { a randomised controlled study of the } \\
\text { beyond blue schools research initiative }\end{array}$ & 57 \\
\hline 2010 & $\begin{array}{l}\text { Benner et } \\
\text { al. (USA) }\end{array}$ & $\begin{array}{l}\text { Latino Adolescents' Experiences of } \\
\text { Discrimination Across the First } 2 \text { Years } \\
\text { of High School: Correlates and } \\
\text { Influences on Educational Outcomes }\end{array}$ & 49 \\
\hline 2011 & $\begin{array}{l}\text { Bear et al. } \\
\text { (USA) }\end{array}$ & $\begin{array}{l}\text { Delaware School Climate } \\
\text { Survey-Student: Its factor structure, } \\
\text { concurrent validity, and reliability }\end{array}$ & 47 \\
\hline 2010 & $\begin{array}{l}\text { Mitchell et } \\
\text { al. (USA) }\end{array}$ & $\begin{array}{l}\text { Student and Teacher Perceptions of } \\
\text { School Climate: A Multilevel } \\
\text { Exploration of Patterns of Discrepancy }\end{array}$ & 46 \\
\hline 2011 & $\begin{array}{l}\text { Gregory et } \\
\text { al. (USA) }\end{array}$ & $\begin{array}{l}\text { The Relationship of School Structure } \\
\text { and Support to Suspension Rates for } \\
\text { Black and White High School Students }\end{array}$ & 46 \\
\hline
\end{tabular}

The top ten most cited publications were tabulated above (see Table II), showing that authors whose articles were written in English and affiliated with English spoken countries were favored by the research community. Seven of the 10 articles were published in the year of 2010. Topics in relation to impacts of school climate as support systems on students' psychological health and well-being stand first with both high quantity and quality status of scientific productions and citations.

\section{B. Publication Patterns by Languages and Countries/Territories}

With regard to the language level analysis, the prolific language within the field of research is English on all entries retrieved from the ISI WoS database with $94.53 \%$ of the total records, whereas the number of publications in non-English language is less than $6 \%$ of all categories under investigation. Unsurprisingly, total school climate publications in English received most citations and the highest citation rate with a GCS of 5589 (94\%), PISA publications receive a GCS of $3772(98.51 \%)$. The high capture rate of English scientific outputs can be explained by high visibility of and preference for the English language for scholarly communications around the globe. Furthermore, it is again confirm that journals indexed by ISI WoS are generally in favor of articles written in the English language (see Table III).

Country/territory-level analyses reveal that that 475 records retrieved in this study were done by authors in 43 countries. USA, with 281 documents $(59.16 \%)$, was the most productive country with the highest citation rate (GCS of $2698,61.12 \%$ ), followed by Turkey (GCS of $63,1.43 \%$ ) and Canada (GCS of 304, 6.89\%). with 26 and 25 documents, respectively. China with 20 documents (GCS of 158, 3.58\%) ranked on the $4^{\text {th }}$ place in publication records and the $3^{\text {rd }}$ place on GCS. The top ten countries publishing more than $92 \%$ of school climate studies indexed in the ISI WoS during 2010 to 2016, as shown in Table IV. Results of the country/territory-level analyses of the present undertaking confirm an earlier finding on far-reaching impacts of English publications on a wide variety of research studies on educational environments.

TABLE III: Publication PATterns By the ToP 10 PRoductive LANGUAGES

\begin{tabular}{lrrrr}
\hline \hline Language & Recs & $\% /$ Recs & GCS & $\% / G C S$ \\
\hline English & 449 & $94.53 \%$ & 3772 & $98.51 \%$ \\
Spanish & 12 & $2.53 \%$ & 36 & $0.94 \%$ \\
German & 4 & $0.84 \%$ & 9 & $0.24 \%$ \\
Turkish & 4 & $0.84 \%$ & 6 & $0.16 \%$ \\
Afrikaans & 2 & $0.42 \%$ & 0 & $0.00 \%$ \\
Croatian & 2 & $0.42 \%$ & 3 & $0.08 \%$ \\
Dutch & 1 & $0.21 \%$ & 0 & $0.00 \%$ \\
Portuguese & 1 & $0.21 \%$ & 3 & $0.08 \%$ \\
\hline \hline
\end{tabular}

TABLE IV: PUBlicAtion PATTERnS By the TOP 10 PRODUCTIVE COUNTRIES/TERRITORIES

\begin{tabular}{lrrrr}
\hline Language & Recs & $\% /$ Recs & GCS & $\% / G C S$ \\
\hline USA & 281 & $59.16 \%$ & 2698 & $61.12 \%$ \\
Turkey & 26 & $5.47 \%$ & 63 & $1.43 \%$ \\
Canada & 25 & $5.26 \%$ & 304 & $6.89 \%$ \\
Peoples R China & 20 & $4.21 \%$ & 158 & $3.58 \%$ \\
Spain & 20 & $4.21 \%$ & 114 & $2.58 \%$ \\
Israel & 19 & $4.00 \%$ & 115 & $2.61 \%$ \\
South Africa & 15 & $3.16 \%$ & 30 & $0.68 \%$ \\
Australia & 12 & $2.53 \%$ & 133 & $3.01 \%$ \\
Germany & 12 & $2.53 \%$ & 58 & $1.31 \%$ \\
South Korea & 9 & $1.89 \%$ & 52 & $1.18 \%$ \\
\hline \hline
\end{tabular}

\section{Publication Patterns by Source Titles and Subject Areas}

A total of 220 source titles publishing school climate studies have been documented by the ISI WoS during 2010 to 2016. Journal of School Health, with 17 records (3.58\%) and the second highest GCS of 209 (5.46\%), is the most productive journal on school climate research, followed by School Psychology Health, with 16 records (3.37\%) and 190 GCS (4.96\%) and Journal of School Psychology, with 13 records $(2.74 \%)$ and 193 GCS (5.04\%). Worth noting is that Journal of Educational Psychology receives the highest GCS of $247(6.45 \%$ ) among the top ten productive journals on school climate research. The relatively lower citation impact of records published by School Mental Health in comparison to its high publication records can be partly explained by the journal's starting year of accepting papers on school climate. 
The top ten productive journals contain 111 entries, as displayed in Table $\mathrm{V}$, counting for $23.37 \%$ of the total number of school climate publications.

A subject area analysis was performed to identify the trend of primary subject areas generated from literature on school climate. Since future research are derived from theoretically led insights and empirically led quest, subject areas analysis would be informative about the development of research directions and emerging topics for further investigations. The ISI WoS database was used to retrieve primary subject areas for each record. The analysis reveals that the field of Psychology, with 230 entries (48.21\%), is the prominent subject area within which research on school climate has been carried out, followed by 174 records (36.63\%) within Educational Research, 57 records within Public Environmental Occupational Health (12.00\%), 32 in Social Work (6.74\%) and 31 in Family Studies (6.53\%) (Fig. 2).

TABLE V: PUBLICATION PATTERNS By THE TOP 10 SOURCE TITLES

\begin{tabular}{lcccc}
\hline \hline Journal & Recs & $\begin{array}{l}\% \\
\text { Recs }\end{array}$ & GCS & $\% / \mathrm{GCS}$ \\
\hline 1 JOURNAL OF SCHOOL & 17 & $3.58 \%$ & 209 & $5.46 \%$ \\
$\begin{array}{l}\text { HEALTH } \\
\text { 2 SCHOOL PSYCHOLOGY }\end{array}$ & 16 & $3.37 \%$ & 190 & $4.96 \%$ \\
$\begin{array}{l}\text { QUARTERLY } \\
\text { 3 JOURNAL OF SCHOOL }\end{array}$ & 13 & $2.74 \%$ & 193 & $5.04 \%$ \\
$\begin{array}{l}\text { PSYCHOLOGY } \\
\text { 4 AMERICAN JOURNAL OF }\end{array}$ & 11 & $2.32 \%$ & 123 & $3.21 \%$ \\
$\begin{array}{l}\text { COMMUNITY PSYCHOLOGY } \\
\text { 5 JOURNAL OF YOUTH AND }\end{array}$ & 10 & $2.11 \%$ & 163 & $4.26 \%$ \\
$\begin{array}{l}\text { ADOLESCENCE } \\
\text { 6 JOURNAL OF }\end{array}$ & 9 & $1.89 \%$ & 247 & $6.45 \%$ \\
$\begin{array}{l}\text { EDUCATIONAL } \\
\text { PSYCHOLOGY }\end{array}$ & & & & \\
7 PSYCHOLOGY IN THE & 9 & $1.89 \%$ & 102 & $2.66 \%$ \\
$\begin{array}{l}\text { SCHOOLS } \\
\text { 8 SCHOOL MENTAL HEALTH }\end{array}$ & 9 & $1.89 \%$ & 37 & $0.97 \%$ \\
9 TEACHING AND TEACHER & 9 & $1.89 \%$ & 63 & $1.65 \%$ \\
$\begin{array}{l}\text { EDUCATION } \\
\text { 10 JOURNAL OF RESEARCH }\end{array}$ & 8 & $1.68 \%$ & 135 & $3.53 \%$ \\
\hline ON ADOLESCENCE & & & & \\
\hline \hline
\end{tabular}

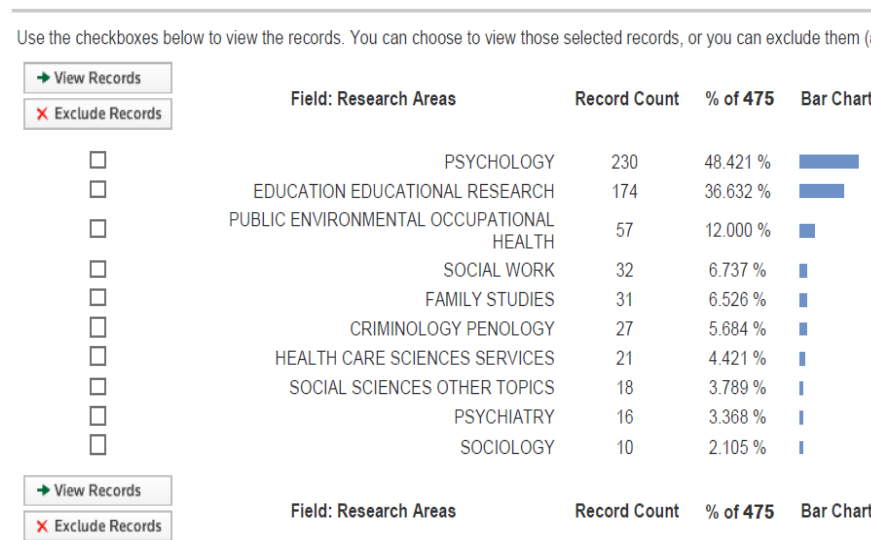

Fig. 2. Publication patterns by source titles and subject areas

\section{DISCUSSIONS AND CONCLUSION}

The bibilometric study aimed to evaluate the scientific production and research trends of school climate research tracked by the ISI WoS. A raising interest in research on school climate came into existence since 1990s, indicating literature on school climate is a sustainable area of research and the past decade has witnessed growing interest in international studies on school climate.

Despite the fact that methods used to quantitatively analyze and synthesize academic literature have distinct contributions, they are having several perceived threats and biases. The current bibliometric study is limited to the selection of ISI WoS database to detect research published in journals. However, this limitation can be alleviated by the fact that academia worldwide has used impact factors provided by ISI WoS as one criterion for promotion or tenure. To generate a complete pool of school climate literature, follow-up studies may include more data sources, such as EI Compendex, SciVerse Scopus and Google Scholar, to give a more accurate representation of relevant research output. The current study, therefore, can be enhanced by conducting co-authorship, author co-citation, document co-citation analysis for revealing more research patterns and dynamics in the CALL literature [8], [9], [10]. To advance our understanding about research tendency and hotspots of this field, another opportunity for future research is to statistically analyze author keyword, key word plus and word cluster analysis [9], [10], [11].

The present study attempted to build on ongoing and past research efforts on school climate by employing conventional biliometric methods incorporating citation analysis to quantify and hotspot past school climate research trend for the purpose of establishing future research directions. Publication characteristics and citation frequencies analyzed would be useful for school climate researchers as patterns and trends revealed by this current study could lead to informed decisions on their future research endeavors and selections of publishing their studies in suitable journals. Overall, this study should not be regarded as offering definitive results of the school climate literature; rather, it supports the values of alternative research perspectives for mapping the scientific structure reflected in published literature in the field of school climate research. Most importantly, this study opened up new avenues for continuous bibliometric investigations of school climate literature for generating unique insights into the direction of not only a particular data source during a given time frame, but also the research dynamics and evolution within which the literature on school climate exists.

\section{ACKNOWLEDGMENT}

This research was funded by a research grant from the Ministry of Science and Technology in Taiwan (MOST-106-2410-H-130-015-MY2).

\section{REFERENCES}

[1] W. K. Hoy and J. W. Hannum, "Middle school climate: An empirical assessment of organizational health and student achievement," Educational Administration Quarterly, vol. 33, no. 3, pp. 290-311. August 1997.

[2] R. L. Sinclair, "Elementary school educational environments: Toward schools that are responsive to students," National Elementary Principal, vol. 49, pp. 53-58, April 1970.

[3] W. K. Hoy, J. Hannum, and M.Tschannen-Moran, "Organizational climate and student achievement: A parsimonious and longitudinal view," Journal of School Leadership, vol. 8, no. 4, pp. 336-359, July 1998.

[4] A. Thapa, J. Cohen, S. Guffey, and A. Higgins-D'Alessandro, “A review of school climate research," Review of Educational Research, vol. 83 , no. 3, pp. 357-385, September, 2013. 
[5] W. K. Hoy and S. I. Clover, "Elementary school climate: A revision of the OCDQ" Educational Administration Quarterly, vol. 22, no.1, pp. 93-110, February 1986.

[6] W. K. Hoy, J. Hoffman, D. Sabo, and J. Bliss, "The organizational climate of middle schools: The development and test of the OCDQ-RM," Journal of Educational Administration, vol. 34, no. 1, pp. 41-59, February 1996.

[7] W. K. Hoy, P. A. Smith, and S. R. Sweetland, "The development of the organizational climate index for high schools: Its measure and relationship to faculty trust," The High School Journal, vol. 86, no. 2, pp. 38-49, December 2002.

[8] W. Hood and C. Wilson, "The literature of bibliometrics, scientometrics, and informetrics", Scientometrics, vol. 52, no. 2, pp. 291-314, November 2004.

[9] B. Cronin, "Bibliometrics and beyond: Some thoughts on web-based citation analysis," Journal of Information science, vol. 27, no. 1, pp. 1-7, February 2001.

[10] F. Osareh, "Bibliometrics, citation analysis and co-citation analysis: A review of literature I" Libri, vol. 46, no. 3, pp. 149-158, October 1996.

[11] R. N. Kostoff, D. R. Toothman, H. J. Eberhart, and J. A. Humenik, "Text mining using database tomography and bibliometrics: A review," Technological Forecasting and Social Change, vol. 68, no. 3, pp. 223-253, November 2001.

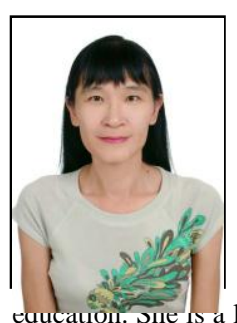

Hui-Wen Vivian Tang is a professor and the chair of the teacher education center, and currently assigned as the dean of Institute of General Education of Ming Chuan University, Taiwan. In 2007, she received an Ed.D degree from the educational leadership program of Texas A \& M University, Kingsville, Texas, USA. Her current research focuses on leadership development, emotional intelligence, cross-cultural studies, multiple criteria decision making and teacher ifelong member of the Emotional Intelligence Training and Research Institute (EITRI) organized by a collegial association located in Corpus Christi, Texas, USA, and formerly the chief editor of "Journal of Applied English". Prof. Tang's recent publications include "Forecasting performance of Grey Prediction for education expenditure and school enrollment" published in 2012 by Economics of Education Review (SSCI), "On the fit and forecasting performance of grey prediction models for China's labor formation" published in 2013 by Mathematical and Computer Modelling (SCI), "Constructing a competence model for international professionals in the MICE industry: An analytic hierarchy process approach" in 2014 by Journal of Hospitality, Leisure, Sport \& Tourism Education (SSCI), "Developing a short-form measure of personal excellence for use among university students in Taiwan" in 2015 by Total Quality Management $\&$ Business Excellence (SSCI), and "On the fit and forecasting performance of grey prediction models for projecting educational attainment" by Kybernetes in 2016 (SCI)., and "Critical factors for implementing a programme for international MICE professionals: A hybrid MCDM model combining DEMATEL and ANP" in 2017 by Current Issues in Tourism (SSCI).

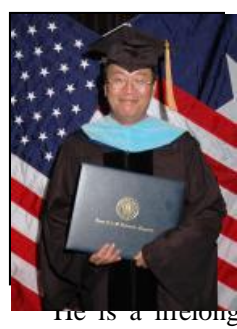

Mu-Shang Yin is an associate professor in the Department of Travel Management of Hsing Wu University, Taiwan. In 2007, he received an Ed.D degree from the educational leadership program of Texas A \& M University, Kingsville, Texas, USA. Her current research focuses on leadership development, structural equation modeling, psychometrical analysis, multiple criteria decision making and tourism education.

member of the Emotional Intelligence Training and Research Institute (EITRI) organized by a collegial association located in Corpus Christi, Texas, USAProf. Yin's recent publications include "Forecasting performance of Grey Prediction for education expenditure and school enrollment" published in 2012 by Economics of Education Review (SSCI), "On the fit and forecasting performance of grey prediction models for China's labor formation" published in 2013 by Mathematical and Computer Modelling (SCI), and Fifteen years of grey system theory research: A historical review and bibliometric analysis in 2013 by Expert Systems with Applications. 